Cephalopoda-bed have been included by the late Dr. Wright and others in their published works in the term "Pea Grit," and he refers me to the paper by Dr. Wright on the so-called sands of the Inferior Oolite" as showing that I am in error. I have referred to the paper cited, and find that in the section (Fig. 1) only one bed is shown as including the Pea Grit and the underlying beds, although in the explanation at foot it is called "Pea Grit and ferruginous oolite," and marked A B C; but the description in the following page is headed "Pea Grit (Inferior Oolite)," and under this heading the beds $\mathrm{A}$ B and $\mathrm{C}$ are described: the description of $\mathrm{A}$ and $\mathbf{B}$ appears, however, to be substantially the same.

In Dr. Wright's latest work " Monograph on the Lias Ammonites" the section of Leckhampton Hill is repeated (fig. 11, page 151); and on reference to the description (p. 152), I find the heading is "Pea Grit (Zone of Harpoceras Murchisonia, Inferior Oolite)," the subdivision being the same as before, and the description being wholly under this beading.

I think the meaning is clear, namely, that it was intended that the term "Pea Grit" should apply to all the beds, although, for the purpose of giving a more accurate description, a subdivision of them was convenient.

Mr. Wethered refers me to Dr. Wright's section of Cleeve Hill, but the extract is incorrectly given, doubtless an error in printing.

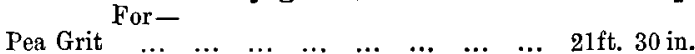

$$
\begin{aligned}
& \begin{array}{llllllll}
\text { Coarse ferruginous oolite } & \ldots & \ldots & \ldots & \ldots & \ldots & \ldots & 22 \mathrm{ft} . \\
5
\end{array} \\
& \text { Read- }
\end{aligned}
$$

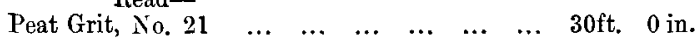

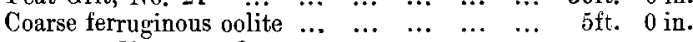

The correct reading confirms my statement, except as regards the lower $5 \mathrm{ft}$.

The section of Cleeve Hill is also repeated in the monograph on the Lias Ammonites (fig. 12, p. 155), and in the description (p. 161) the beds are called "Pea Grit," and the three subdivisions are described in much the same language as is used in the description of the beds at Leckhampton.

EDwis Witchell.

\title{
CORRECTION OF MIOCENE INSECTIVORA.
}

Sir,-With your permission I will avail myself of the Geologrcar Magazine to correct an error into which I have been led by the writings of others in part $i$. of the "Catalogue of Fossil Mammalia in the British Museum" (1875).

On page 19 of that volume I followed Dr. O. Fraas' in identifying the Auvergne Plesiosorex soricinoides (Erikaceus soricinoides, of Blainville) with Parasorex socialis, Meyer, of Steinheim. Having recently, however, had cause to consider further the affinities of the Miocene Insectivora, I have been led from an examination of the figures given by Fraas and De Blainville to the conclusion that the identifications made by the former writer are totally erroneous. The Steinheim Parasorex socialis is, as Fraas states, closely allied to 1 “Fauna von Steinheim," p. 4 (1870). 
Tupara, while Plesiosorex soricinoides is a totally different form, whose affinities, as stated by Pomel, are rather with Myogale. I am further led to conclude that Fraas' identification of Erikaceus arvernensis of De Blainville, with Plesiosorex soricinoides is likewise erroneous, and that the fauna is probably identical with $E$. arternensis of Gervais. ${ }^{1}$

The specimen entered in the Museum Catalogue under the name Plesiosorex must therefore be named Parasorex, and the former genus referred to the Talpida. This error will be noticed in the supplement to be published in part v. of the Museum Catalogue; but as the publication of that part will be several months hence, I have thought it advisable to correct the error as soon as possible.

HARPENDEN, Dec. 10, 1886.

R. LYDEKKER.

\section{ON THE OSBORNE BEDS.}

SIR,-I wish to correct a mis-statement of my views respecting the position of the Osborne Beds, which appears in the Report of the International Geological Congress for 1885, and also I find is repro. duced in Mr. Jukes-Browne's new Handbook of Historical Geology. My opinion has always been that the Osborne Beds should have been a part of the Bembridge Series, and not a separate member.

Woodwardian Museum,

Cambridge.

H. Keeping.

\section{THE COLLINGHAM OR SCARLE BORING.}

Str, - In the recently issued Report of the British Association for $1885, \mathrm{pp} .388,389$, the original inaccurate account of this boring is reproduced, and $I$ am credited with the alternative figures given in a second column.

Permit me to state that I have published no account of the boring, and that the figures alleged to be mine do not coincide with the section preserved among my papers, viz. :-

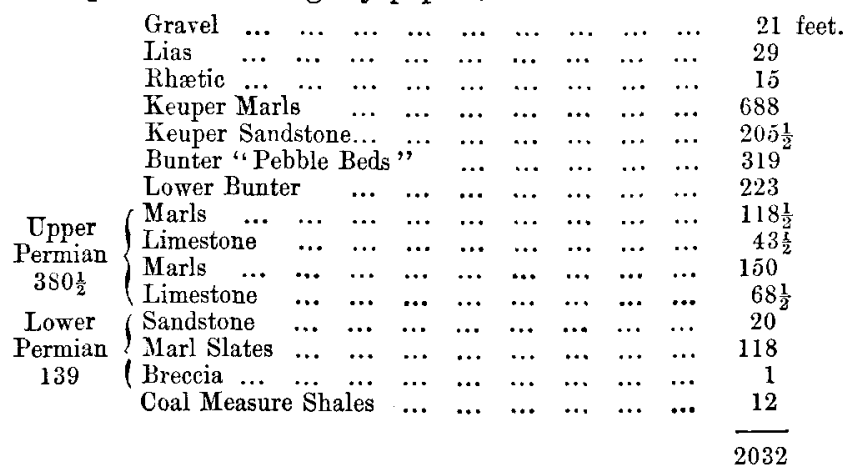

The site is not in the parish of Scarle, Lincolnshire, but in Collingham, Notts.

W. H. Dalton, F.G.S.,

Late H.M. Geological Survey.

1 See "Cat. Foss. Mamm. Brit. Mus." pt. i. pp. 17, 18. 